\title{
TURGENEV'S DOCTOR SHPIGELSKY: A PROTOTYPE FOR SHAW'S PROFESSOR HIGGINS?
}

\author{
Sigrid Renaux \\ Universidade Federal do Paraná.
}

\begin{abstract}
SUMMARY:
This paper intends to establish some parallelisms between Doctor Shpigelsky, a country doctor in Turgenev's play A Month in the Country, and the famous Professor Higgins, in Shaw's Pygmalion. In spite of differing in almost every other aspect, these two characters display similar attitudes towards women: both feel godlike in their masculine superiority of being able to mould women, one as a future husband, the other as a professor, and both consider women either despicable, or a nuisance, besides being idiots. On the other hand, both men make allowances as to their own chararter, conceding that they are vain, exacting, and bossy. Thus, although the effect of their speeches is different in both plays, for Dr. Shpigelsky's fiancee will probably submit to his wishes, while Elisa Doolittle does rebel in Pygmalion, nevertheless the fundamental parallelısms remain: both characters are the mouthpiece of their authors' ideas on women. As Shaw was probably not acquanted with Turgenev's play, the initial question remains: how far is $\mathrm{Dr}$. Shpigelsky a prototype for Prof. Higgins, in relation to the parallelisms established above?
\end{abstract}

During the 1981 London performance of Turgenev's play A Month in the Country - in a new translation by Isaiah Berlin commis-

'TURGENEV, 1. A Month in the Country. Trans. and intrad. by Isaiah Berlin. London, The Hogarth Press. 1981. 127 p. Quotations from the play will be indicated by page numbers in the text.

Letras, Curitiba (33) 121-129 - 1984 - UFPR 
sioned by the National Theatre - my attention was called to certain statements made by Ignati llyich Shpigelsky, which sounded familiar to my ears. More specifically, I was reminded of one of Shaw's most famous characters, Professor Higgins in Pygmalion ${ }^{2}$. It occurred to me later that $A$ Month in the Country, written in 1850 but which had reached the English stage only in 1926, was probably not known by Bernard Shaw, for Pygmalion was first presented in London in 1914, and it is rather unlikely that other translations would have been available to Shaw before he had written Pygmalion, or that he has actually read them. (As he declares in a biography by Hesketh Pearson, "I am very sorry; but I cannot learn languages. I have tried hard, only to find that men of ordinary capacity can learn Sanscrit in less time than it takes me to buy a German dictionary" ${ }^{3}$ ). In this manner, the creation of some of Professor Higgins' speeches and attitudes could not have been directly influenced by certain of Doctor Shpigelsky's statements. And this is why the parallelisms we plan to establish between some of these statements are so striking, for although both plays are concerned with social criticism, they differ in almost every other aspect, except these patent similarities which exist in the attitudes Shpigelsky and Higgins display towards women.

A Month in the Country, according to I. Berlin "one of the most admired and frequently acted nineteenth-century plays" called "a comedy in five acts", although it is also considered to be "one of the earliest of Russian psychological dramas"s. It deals with the disruption of life on the country estate of a rich landowner, Islaev, after a young tutor arrives to teach his son. Both Natalia, Islaev's wife and Vera, her young ward, fall in love with Belyaevw. The emotional situation reaches its climax when Natalia discovers that the tutor is in love with her, even if too intimidated by her to declare it. Thus, the tutor decides he has to leave, together with an old family friend, Rakitin, whose love for Natalia also makes his stay become unbearable, while Vera vows to marry an old neighbor in order to leave the house, too also.

Pygmalion, on the other hand, is called "a Romance in five acts", although Shaw himself in his conclusion to the play mentions that Eliza's "little drama" would have been spoiled if she became the heroine

\footnotetext{
${ }^{2}$ SHAW, B. Pygmalion. London, Constable. 1953. 307 p. Quotations from the play will be indicated by page numbers in the text.

3 PEARSON, H. Bernard Shaw: His life and Personality. London. The Reprint Society, 1948.p. 24.

4 TURGENEV, p. 9.

5 TURGENEV. cover.
} 
of a romance by marrying the hero of $\mathrm{it}^{6}$. And the plot of Pygmalion the transformation of a Cockney flower-girl into a lady by being taught how to speak English properly - is too well known to be mentioned again in any more detail.

Turning now to both characters, we shall leave out Shpigelsky's more important role in the play as social critic, for although his remarks amount to a "bitter indictment of a social system which no reader, no member of theatrical audience in Russia in the nineteenth century, could have missed"7 , our aim is to concentrate on that facet of his personality which could project him as a potential prototype for Higgins, and this aspect are his tirades against women. (Of course this aspect is not completely separate from his role as social critic, because he is attacking the feminine Russian gentry of his time. Nevertheless, his speeches can also be accepted as statements against women in general, in the same way that Higgins' statements too, although directed against younger women, are at the same time general enough to comprise the whole of the weaker sex.)

Shpigelsky and Higgins, both fortyish and inveterate bachelors, differ in probably every other aspect, starting with the fact that Shpigelsky, first a "confirmed old bachelor", like Higgins, becomes engaged during the play and is looking towards his married life with Lizaveta Bogdanovna, the governess in the same household where Shpigelsky is the country doctor; while Higgins is a "confirmed old bachelor, and likely to remain so" (P 229), as he tells his mother. Besides, Shpigelsky is described as "astute, corrupt, cynical"8, while Higgins, for all his tyranny and egocentrism, his being "cold, unfeeling, selfish" (P. 292) and even "an arbitrary overbearing bossing kind of person" as he repeats Mrs. Pearce's opinion about himself to Colonel Pickering (P 231), this "bully", this "ramping, swearing boor"9 is brutally honest towards the others. But both men do have this point in common - both feel godlike in their masculine superiority of being able to "mould" women, like Pygmalion, the Cyprian sculptor who made an ivory statue of a woman of such beauty that he fell in love with it and Aphrodite, taking pity on the lover, made the statue become alive in his arms.

In relation to Shpigelsky this becomes apparent when he speaks to his future fiancée about their married life, commenting to her that "a wife is like wax in the hands of a good husband" (MC 88). And this is exactly what Higgins does in relation to Eliza - even if the relationship

"SHAW, p. 295.

7 TURGENEV, p. 13.

'TURGENEV, p. 12.

"EVANS, T. F., ed. Shaw; The Critical Heritage. London, Routledge \& K. Paul, 1976. p. 228.

Letras, Curititul (33) $121 \cdot 129 \cdot 1984 \cdot$ UFPR 
is one of teacher-pupil, which nevertheless resembles a husband-wife relationship in the play - for Higgins will turn a "squashed cabbage leaf" (P 210) into a duchess, as he says to Cel. Pickering:

You see this creature with her kerbstone English; the English that will keep her in the gutter to the end of her days. Well, sir, in three months I could pass that girl off as a duchess at an ambassador's garden party. I could even get her a place as a lady's maid or shop assistant, which requires better English ( $P$ 210).

In this way, both characters confirm that a man in a superior position, one as a future husband, the other as a professor, can take a woman and change her into a different human being. In this way, both show their basic attitude is the same: men are supposed to change women, for these can be moulded, and this change is not miraculous at all, as in Pygmalion's case, but quite possible, as Shaw himself confirms: "I may add that the change wrought by Professor Higgins in the flower girl is neither impossible nor uncommon" (P 188-9). Women are like "live dolls" in the hands of men, as Professor Higgins' mother also corroborates, while Higgins tries to explain to her what he is actually doing with Eliza:

Mrs. H.: You certainly are a pretty pair of babies, playing with your live dolls.

Higgins: Playing! The hardest job I ever tackled: make no mistake about that, mother. But you have no idea how frightfully interesting it is to take a human being and change her into a quite different human being by creating a new speech for her (...) It's the most absorbing experiment I ever tackled. (. . ) (O. 256).

Margery M. Morgan also confirms this idea, as she comments:

The Professor in the haven of his laboratory, absorbed in the fascination of his special study and careless of any other concerns, appears to his own mother as a baby playing with toys, with the peculiar irresponsibility of the baby, not realizing that its "doll" is a human being with human feelings who has to go on living in a bigger, more complicated world outside the laboratory. The imperative implied is that every man ought to see what he is doing in relation to the whole society in which he lives, in the con- 
text of its values and his own"10.

Besides both Shpigeslky and Higgins being convinced that women could and should be changed, even if for different reasons - for they are "live dolls" - and besides the fact that Shpigelsky speaks about what he intends to do with his future wife, while Higgins actually does change Eliza, there is another parallelism apparent in their attitudes towards women: women are either despicable, or a nuisance, and idiots.

Again, although Shpigelsky speaks about the noble ladies of his generation and which he has to serve as a doctor, coming as he does from a lower class, while Higgins belongs to the upper class and even despises his equals and superiors in a certain way, there can again be detected points of contact between both men, for similarities are even more evident. As Shpigelsky confides to his fiancée, in his bitter indictment of "fine ladies".

Oh, these ladies! they smile at you, make eyes at you like that - but you can see it on their faces. . . they feel nothing but disgust for us . . . and what can you do? I understand all too well why she (Natalya Petrovna) said horrid things about me today. Really, these fine ladies are extraordinary beings! Just because they wash in eau de Cologne every day, and don't mind what they say and scatter their words carelessly, for you and me to pick up as best we can - because of that these ladies imagine that one can't catch them by the tail. But thet's not so at all. They are no different from the rest of us - sinful mortals like us all (MC 89).

Higgins likewise abuses women when he tells his mother

Oh, I cant be bothered with young women. My idea of a lovable woman is somebody as like you as possible. I shall never get into the way of seriously liking your women: some habits lie too deep to be changed. (. . .) Besides, they're all idiots. (P. 245).

Both men reaffirm again their authority and what they dislike in relation to women when they discuss their own character. Shpigelski, by confiding to Lizaveta:

${ }^{10}$ MORGAN. M. M. The Shavian Playground. London, Methuen, 1972. p. 170-1.

Letras, Curitibo (33) 121-129 - 1984 - UFPR 
If I am well served and have all my wishes attended to, I'm not against that; and I like people to take note of my habits, and provide me with good food. I'm not jealous, by the way, or mean, and when I'm not there you can do what you like. There is, of course, no question of anything like romantic love between us - you do realize that, I imagine. But $I$ think that it's possible to live under the same roof with me. . . provided everything is done the way I like it. And no tears while I'm about. I can't stand tears. And I don't nag or find fault all the time. There's my confession for you. Well, ma'am, what do you say to that? (MC 90).

And, after having condescended in calling her "a sensible woman" (MC 91), as Higgins had also made an exception with his mother, Shpigelsky finishes by letting Lizaveta Bogdanovna know that

I'm tremendously inquisitive myself, but I can't bear inquissitive women - I mean - let me explain: in my book a wife must be both curious and observant (which can actually be very useful to her husband), but only provided that it's directed towards other people. . . do you follow me: only other people. (MC 91 - 2).

He nevertheless makes allowances as to his own character, when he "warns" Lizaveta that, besides being "extremely vain", "at home I'm liable to be rather gloomy, silent, exacting" (MC 90).

Higgins, similarly, confides to Cel. Pickering that

I find that the moment I let a woman make friends with me, she becomes jealous, exacting, suspicious, and a damned nuisance. I find that the moment I let myself make friends with a woman, I become selfish and tyrannical. Women upset everything. When you let them into your life, you find the woman is driving at one thing and youre driving at another.

Pick: At what, for example?

Higgins: (. . .) Oh, Lord knows! I suppose the woman wants to live her own life; and the man wants to live his; and each tries to drag the other on to the wrong track. One wants to go north and the other south; and the result is that both have to go east, though they both hate the east wind. (. .) (P. 228-9) 
Nevertheless, he seems to resent his governess being persuaded that he is "an arbitrary overvearing bossing kind of person" (P 231).

This war of sexes which Higgins prognosticates seems to be avoided beforehand by Shpigelsky who, as an old bachelor, intends to get married in order to have somebody look after him, but who thinks "it is possible to live under the same roof with me ... provided everything is done the way I like it" (see above), while Higgins is a bachelor and "likely to remain so", in order to avoid having to "go east".. .

Thus, Shpigelsky is a Pygmalion in potential, Higgins one in deed. One intends to marry in order to mould his wife like wax according to his will, for she will have to attend to all his wishes, while the other, although he has changed his pupil's "form" according to his talent as a professor of Phonetics, he can't bear the idea of having to adapt himself to any woman, even Eliza.

And both men resent another aspect in women: their supposed "acting" towards men. As Shpigelsky warns Lizaveta that she shouldn't act in front of him, when he asks her if they should talk about their "own affairs" (MC 88),

Come, Lizaveta, what is the point of all this acting, all this coy fluttering of eyes lids, may I ask? After all, we aren't exactly young, you and $I$. These affectations, these soft airs and sighs - it's all slightly absurd at our age. Let's talk this over quietly, in a businesslike manner, as befits our years. (MC 88).

Higgins similarly complains to Eliza of the "tricks" she has set up "of fetching and carrying slippers against my creation of a Duchess Eliza" (P 290).

Interestlingly enough, in A Month in the Country there is another character, Rakitin, who seems to embody the Pygmalion myth in reverse, for he is a living example of what may happen to a man who "submits" to the woman he loves, and thus he could stand for what might happen to either Shpigelsky or Higgins, if they stopped being authoritarian. As Rakitin warns the young tutor Belyaevrv - with whom Natalya Petrovna, the woman Rakitin loves, is in love - about the danger of submitting completely to to love,

I believe, Alesksei Nikolaich, that every kind of love, whether happy or unhappy, is a real calamity if you surrender to it wholly. . Wait! You may yet come to know how those gentle little hands can torture, with what solicitous tenderness they can rend the heart into little pieces... 
Just wait - you'll discover how much burning hatred is hidden within the most ardent love! You will think of me when you long for peace as a sick man longs for health, the most meaningless, commonplace kind of peace - when you will envy any man who is light-hearted and free. . You wait! You'll find out what it means to be tied to a petticoat, to be a woman's slave, to feel the poison in one's veins - and how humiliating, how agonising such slavery is! ... and finally, you'll learn what miserable trifles are bought at such high cost. . (MC 111-112)

And Rakitin ends his advice by commenting that "women - are very capricious creatures" (MC 112), words that could be spoken either by Shpigelsky or by Higgins himself.

In this way, Rakitin, the dominated lover, the person who is like wax in a woman's hands, serves as a gauge against which to measure the weight of the other two men, the first a domineering husband to be, the other the domineering professor. Rakitin serves as a confirmation to what will happen, if men do fall in love and submit to women. (In a lesser degree, this is what Freddy in Pygmalion does, in relation to Eliza). Nevertheless, the other alternative would not please women either having to submit to the men who have changed or who plan to change their original "mould", for as Shaw comments on the outcoming of Pygmalion, "Eliza likes Freddy and she likes the Colonel; and she does not like Higgins and Mr. Doolittle. Galatea never does quite like Pygmalion; his relation to her is too godlike to be altogether agreeable" (P 307).

Having thus established the similarities that underlie Shpigelsky's and Higgins' attitudes towards women and which become apparent through their speeches in both plays, as also, with a minor emphasis, the reverse side of the coin, that is, what may happen when a man surrenders wholly to love - or to women - through Rakitin and Freddy lalthough Rakitin has no chance of marrying Natalye while Freddy does marry Elizal, we can conclude by saying that both Turgenev and Shaw have, for different reasons, made Shpigelsky and Higgins become the mouthpiece for their ideas on women. By the fact that the effect of their speeches is ironical, for both Shpigelsky and Higgins are ironized in their tirades, both playwrights seem to convey the view that "self-respect and independence of spirit" are "the only reliable bases for an egalitarian society" and for "a new, unconstrained, affectionate relation between the sexes."11

${ }^{11}$ EVANS, p. $173-4$ 
And the initial question remains: as Shaw was probably not acquainted with Turgenev's play, how far is Doctor Shpigelsky a prototype for Prof. Higgins, in relation to the parallelisms established above?

\section{RESUMO:}

Este trabalho pretende estabelecer alguns paralelismos entre o Doutor Shpigelsky, um médico na peça A Month in the Country, de Turgenev, e o famoso Professor Higgins, na peça Pygmalion de Shaw. Apesar de diferirem em quase todos os outros aspectos, essas duas personagens apresentam atitudes semelhantes em relação as mulheres: ambos sentem-se como deuses em sua superioridade masculina de poder moldar as mulheres, um como futuro marido, e outro como professor, e ambos consideram asmulheres desprezáveis, incômodas e idiotas. Por outro lado, ambos tomam em consideração suas próprias personalidades, reconhecendo serem vaidosos, exigentes e mandões. Assim, apesar de o efeito de suas falas ser diferente em ambas as peças, pois a noiva do Dr. Shpigelsky provavelmente se submeterá a seus desejos, enquanto Elisa Doolittle chega a se rebelar em Pygmalion, no entanto os paralelismos básicos permanecem: ambas as personagens são porta-voz das idéias de seus autores sobre as mulheres.. Como Shaw provavelmente não conhecia as obras de Turgenev, a pergunta inicial permanece: até que ponto o Dr. Shpigelsky é um protótipo do Prof. Higgins, em relação aos paralelismos estabelecidos?

\section{BIBLIOGRAPHICAL REFERENCES:}

1 EVANS, T. F., ed. Shaw; The Critical Heritage. London, Routledge \& K. Paul, 1976. $422 \mathrm{p}$.

2 MORGAN, M. M. The Shavian Playground. London, Methuen, 1972. 366 p.

3 PEARSON, H. Bernard Shaw; His Life and Personality. London, The Reprint Society, 1948. $448 \mathrm{p}$.

4 SHAW, B. Pygmalion. London, Constable, 1953. 307 p.

5 TURGENEV, I. A Month in the Country. Trans. and introd. by Isaiah Berlin. London, The Hogarth Press, 1981. 127 p. 